\title{
HISTOCHEMICAL CHANGES OF NUCLEIC ACIDS IN THE FOLLICULAR STROMA OF THE RABBIT'S OVARY BEFORE AND DURING OVULATION
}

\author{
SARDUL S. GURAYA \\ Department of Zoology, University of Udaipur, \\ Udaipur, Rajasthan, India \\ (Received 12th May 1970, revised 27th July 1970)

\begin{abstract}
Summary. The densely packed cells of the theca externa of the oestrus follicle of the rabbit contain cytoplasmic RNA which stains well with methyl green-pyronine and their nuclei give a strongly positive reaction with Feulgen's method. During the period of preovulatory swelling, DNA and RNA are much reduced in these cells and disappear almost completely from the cells in the area of stigma.
\end{abstract}

Morphological, histochemical and biochemical changes associated with preovulatory swelling and ovulation have been studied in the follicular fluid, membrana granulosa and theca interna of follicles in the rabbit and other mammals (Blandau, 1966; Guraya, 1968; Loraine \& Bell, 1968). No attempt has so far been made to study nucleic acid changes in the surrounding stroma during preovulatory swelling and ovulation, though morphological changes within the stroma during preovulatory swelling and ovulation have been described (Blandau, 1966, 1967; Espey, 1967; Loraine \& Bell, 1968).

Mature New Zealand giant white rabbits were used throughout. Details of materials were the same as those described previously (Guraya, 1968). The ovaries were fixed in Carnoy's or Zenker's fluid, embedded in paraffin wax and sectioned at $10 \mu$. For the study of RNA in the material fixed in Zenker's fluid, the methyl green-pyronine techniques were used (Jordan \& Baker, 1955; Kurnick, 1955, cited in Pearse, 1961). Control sections were pretreated with ribonuclease and trichloracetic acid (Pearse, 1961). For the study of DNA in the material fixed in Carnoy's or Zenker's fluid, the Feulgen reaction reported by Pearse (1961) was used; control sections were pretreated with $4 \%$ trichloracetic acid at $90^{\circ} \mathrm{C}$ for $15 \mathrm{~min}$ (Schneider, 1945, cited in Pearse, 1961).

Lying outside the theca interna of fully grown follicles in the ovaries of oestrous rabbits is the broad layer of ovarian stroma, the theca externa, the compactly arranged cells of which have a basophilic cytoplasm which stains red with pyronine. In sections treated with ribonuclease or trichloracetic acid, this quality is lost, indicating that the cells contain RNA. The stromal elements also give a strongly positive reaction with the Feulgen technique together with a negative reaction in control sections treated with $4 \%$ trichloracetic acid at $90^{\circ} \mathrm{C}$ for $15 \mathrm{~min}$. 
The surrounding ovarian stroma of preovulatory follicles in rabbits killed 6 to $10 \mathrm{hr}$ after the administration of HCG showed the gradual development of conspicuous morphological and histochemical changes (PI. 1, Figs. 1, 2). Due to the oedema in the theca externa, the cells were increasingly separated from each other as extracellular fluid accumulated. Some stromal cells reacted less strongly when stained with the methyl green-pyronine and Feulgen techniques. This indicates some loss in the cytoplasmic RNA and nuclear DNA. Such nucleic acid changes were relatively more conspicuous in the stigmal zone and its immediate surroundings in the fully mature follicles (PI. 1, Figs. 1, 2). The histochemical changes in the nucleic acids, which were already visible $1 \mathrm{hr}$ after the intravenous administration of 100 i.u. HCG, were well marked in the surrounding stroma of newly ruptured follicles (PI. 1, Figs. 3, 4). These were surrounded by a wide clear zone, which showed very little histochemically demonstrable RNA and DNA in its loosely arranged stromal elements (PI. 1, Figs. 3, 4). The histochemical changes in the nucleic acids of the cells of the theca externa were more impressive in the sections than in the photomicrographs.

This study shows that the physical and chemical characteristics of the nucleic acids of the stromal cells are apparently altered during ovulation and indicate that it may be useful to study the nature and concentration of enzymes which cause such changes in the nucleic acids. These may be the lysosomal hydrolases, e.g. DNA-ase, RNA-ase, cathepsins (i.e. proteolytic enzymes) which are set free to bring about the observed changes in the nucleic acids (Novikoff, 1961). Both morphological and histochemical changes of surrounding ovarian stroma associated with preovulatory swelling and ovulation suggest that the rupture of the follicles may be due to some catabolizing factors. The results of the histochemical study are strongly supported by the recent observations of Espey \& Lipner (1965) and Espey (1967), who have also found that there is disintegration of the connective tissue elements in the wall of the Graafian follicle before rupture occurs. On the basis of their evidence showing similarities between enzymatically induced rupture of the follicle and coitally induced ovulation, they postulated that the structural changes preceding follicular rupture might be the result of proteolysis. It is becoming increasingly clear that the rupture of a follicle is the end result of a series of definitive changes which occur within the follicular wall, presumably in response to the action of the luteinizing hormone.

\section{REFERENCES}

BL.ANDAU, R. J. (1966) The mechanism of ovulation. In: Ovulation, pp. 1-15. Ed. R. B. Greenblatt. Lippincott, Philadelphia.

Blandau, R. J. (1967) Anatomy of ovulation. Clin. Obstet. Gynec. 10, 347.

Espey, L. L. (1967) Ultrastructure of the apex of the rabbit Graafian follicle during the ovulatory process. Endocrinology, 81, 267.

EsPey, L. L. \& LipNER, H. (1965) Enzyme induced rupture of rabbit Graafian follicle. Am. J. Physiol. 208, 208.

GurAyA, S. S. (1968) A histochemical study of pre-ovulatory and post-ovulatory follicles in the rabbit ovary. F. Reprod. Fert. 15, 381.

LoRAine, J. A. \& BelL, E. T. (1968) Fertility and contraception in the human female. Livingstone, Edinburgh.

Novikorf, A. B. (1961) Lysosomes and related particles. In: The Gell, Vol. 2, pp. 324-488. Eds. J. Brachet and A. E. Mirsky. Academic Press, New York.

PeArse, A. G. E. (1961) Histochemistry. Churchill, London. 


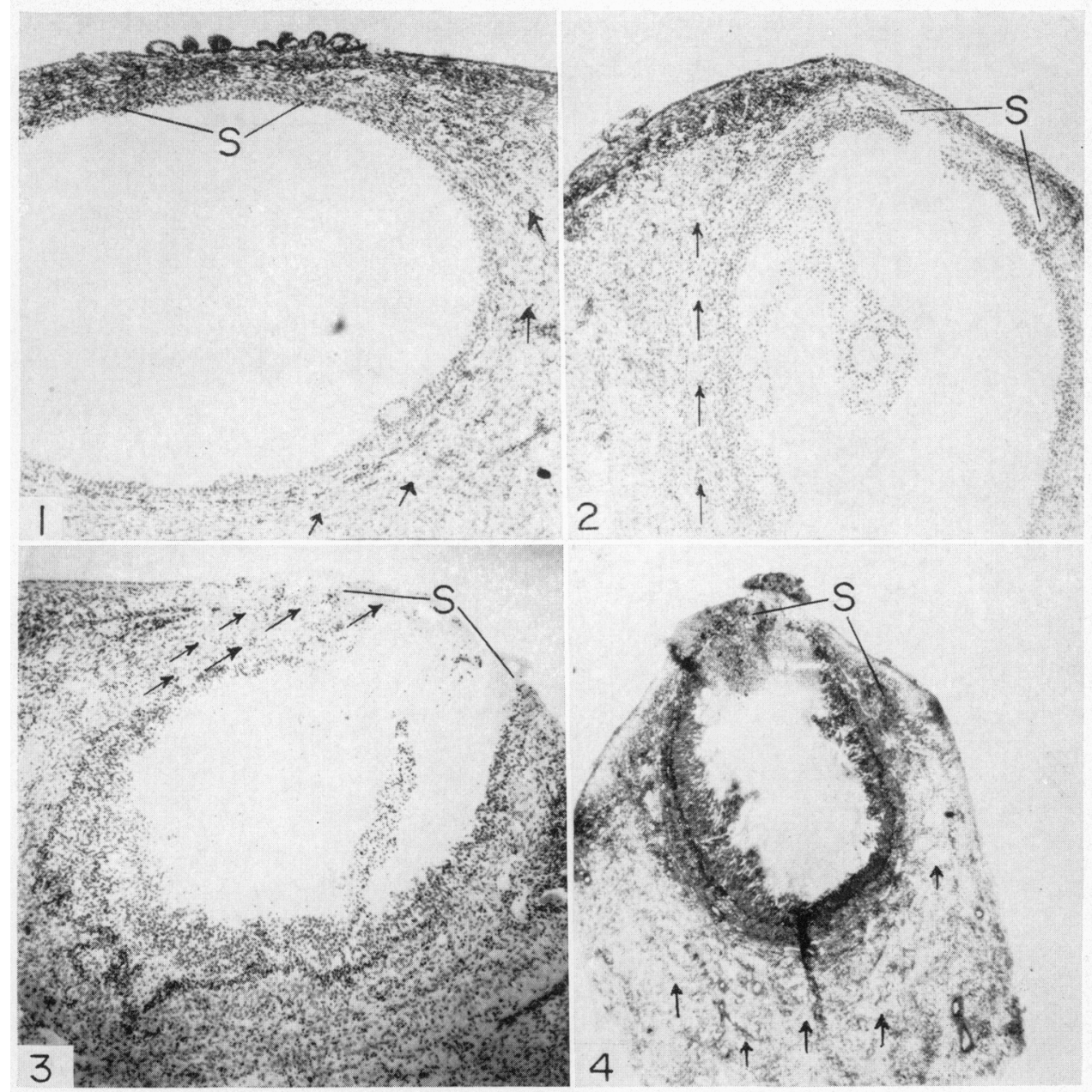

FIG. 1. Photomicrograph of preovulatory follicle, showing very little Feulgen-positive material in the surrounding stroma (arrows), though such material is still quite conspicuous in the stigmal zone $(\mathrm{S})$. The follicle was removed $6 \mathrm{hr} 15 \mathrm{~min}$ after the injection of 100 i.u. HCG, fixed in Carnoy's fluid and Feulgen stained. $\times 84$.

FIG. 2. Photomicrograph of follicle during preovulatory swelling. There is a decrease in the staining of the nuclei of the surrounding stromal cells in the stigmal area(s). The follicle was removed $8 \mathrm{hr}$ after the injection of $100 \mathrm{i} . \mathrm{u}$. HCG and fixed and stained as in Fig. 1. $\times 84$.

FIG. 3. Portion of newly ruptured follicle, showing further disappearance of Feulgenpositive substance from the area of stigma (arrows). The follicle was removed $10 \mathrm{hr} 40 \mathrm{~min}$ after the injection of 100 i.u. HCG, and fixed and stained as in Fig. $1 . \times 84$.

Fig. 4. Portion of newly ruptured follicle, showing the absence of basophilic substance from the surrounding stroma as well as from the area of stigma. The basophilic substances are conspicuous in the cytoplasm of the granulosa and theca interna cells. The follicle was removed $10 \mathrm{hr} 40 \mathrm{~min}$ after the injection of $100 \mathrm{i}$.u. HCG, fixed in Zenker's fluid, and stained with methyl green-pyronine. $\times 42$. 